\title{
Investing in China: Opportunities and Risks in the Future
}

\author{
Yunhua Liu \\ College of Humanities, Art and Social Sciences Nanyang Technological University, \\ Singapore City, Singapore \\ Email: ayuliu@ntu.edu.sg \\ Received February $2^{\text {nd }}, 2012$; revised March $3^{\text {rd }}, 2012$; accepted March $15^{\text {th }}, 2012$
}

\begin{abstract}
Investment environment in China is changing due to the drastic change in world economic environment and the intrinsic evolution inside the Chinese economy. Although China is facing a series challenges for its further growth, a soft landing of the economy is expected. To meet the external and internal challenges and to overcome the constraints for further growth, China has to transit the growth pattern which will generate two areas of new demand, expansion of new industries for green economy and for resources saving goals and promoting the purchasing power of low income group. Fast urbanization and moving to the west are the other two major development opportunities. Risks and uncertainties in the coming time could come mainly from the slowdown of external demand growth, the appreciation of Chinese currency, the labor cost increase, domestic competition and product mimicking, resource supply constraints, and trade disputes.
\end{abstract}

Keywords: Chinese Economy; Investment

\section{Introduction}

Investing in China has been a luscious attraction to the world investors in the past and will still be the same in the future. Low production cost and large market are the two major considerations among others for their business decisions. Recent drastic changes in the world economic environment and the intrinsic evolution in the Chinese economy however caused a wide concern of the uncertainty of investment in China. From investors' perspective, we may ask: What has happened and what will happen in the future to the investment environment in China?

As the world second largest economy, China is now facing a series of challenges from the external and the internal to its further growth. The major concern is the possible hard landing from the previous steadily high growth trend. Clearly, fluctuations from the Chinese economy may generate sizable impacts to the rest of the world, and cause a doubtful expectation to the returns of investment in China too.

The challenges from external are the slowdown of external demand expansion for Chinese products from developed economies, the pressure of Chinese currency appreciation from huge foreign exchange reserve, and the resources price rising due to the money supply increase in the United States. Meanwhile, the economic environment inside China has also changed substantially. Labor cost increase, inflation pressure, environment deterioration, widening income gap and social stability are all emerging as new constraints to China's sustainable development. The Chinese economy is now at a crossroad.

To overcome all the challenges and to keep the growth trend, transition of the growth pattern in Chinese economy becomes inevitable. Chinese government has announced a full plan to cope with all the problems in its $12^{\text {th }}$ five-year plan (20112015), mainly focusing on the promotion of domestic demand and upgrading the industrial structure.

Accompany with the policy changes and the economic envi- ronment change, investment environment in China will certainly encounter some transformation. Different industries and investments could be affected in a different way. This paper tries to evaluate the possible impacts of these changes and to illustrate what the major factors are which affect different aspects of business investments in the future. The rest of the paper is organized as follows. Section two reviews briefly the development policies and the performance of foreign direct investments in China. Section three analyzes and evaluates the changing opportunities and risks of investment in China in the future. Section four concludes.

\section{Development Policies and Performance of FDI in China}

The contributions of foreign direct investment (FDI) in China's thirty years fast growth have been well documented. Direct effects include the provision of capital, new technology, modern management skills and labor employment. Indirect effects could be the spillovers of knowledge, skills, work ethic, and so on (Fung, 2002). It was the complementarity of the capital and technology hungry Chinese economy and the high labor cost developed economies that generated the huge opportunity for FDIs in China under China's new development strategy, the open-door policy since 1978. Foreign capital was attracted to China by China's abundant cheap labor, cheap land and other resources, plus all the policy privileges to FDI's. The main promotion policy for FDIs was the tax incentives and the cheap land. FDIs enjoyed two years tax exemption and three year tax reduction from the central government and could get the cheap land from local governments. By the end of 2010, however, all the tax incentives had phased out except some special industrial sectors. Cheap land is no longer available in the developed coastal areas and big cities. The past thirty years has witnessed the process of maturity of China's FDI policy management, improvement in regulations and changing cultural 
environment favoring the foreign investment. In the last decade, China has maintained to be the main destination of FDIs in the world (Table 1). In 2011, the newly establishment of foreign enterprises were 27,712 in non-financial sectors, mainly in the sectors of manufacturing and real estate. The foreign capital actually utilized was 116.0 billion US dollars, up by 9.7 percent (China Statistical Communiqué 2012, see Table 2).

Policies and prescribed opportunities however could not guarantee the success of business. FDIs in the initial stage in China's development experienced various difficulties in handling all the problems of the unclear policies, unfriendly cultural environment, shortage of infrastructures, shortage of skilled labors and shortage of management skills. Opportunities were plenty, the challenges were harsh too. Failures were not uncommon, even for large investment such as Beijing Jeep project invested by the American company in 1980s (Vanhonacker, 2004).

The performance of FDIs on their investment profitability in China has however a clearly good record. High return is a must. A few survey results showed us the performance of the FDIs in profit returns on the capital and the percentage of satisfaction of their investment in China. The survey conducted by US-China Business Council 2011 on China Business Environment indicates that $60 \%$ of their member companies have the profitability rate in their China operations better than the global rate and more than $80 \%$ of the US companies were profitable in the past six years (Figure 1).

Although some favourable policies toward FDIs phased out in 2010, government pro-investment policies are not changed. New supportive factors and new challenges are both appeared in the new era. In next section, we will examine what changes are happening in China's investment environment, and how these changes affect the investment opportunities and risks in the future.

\section{Investment Opportunities and Risks in the Future}

Both the macro development trend and specific areas in China's investment environment are changing. In this section, we summarize briefly first the macro trend in Chinese economy and government policy, the changes in specific areas for investment, and we then analyze in detail how these changes form opportunities and give rise to risks for investment in the future.

Table 1.

Foreign direct investment in China 2001-2009.

\begin{tabular}{ccc}
\hline Year & $\begin{array}{c}\text { Total Amount of } \\
\text { Contracted Foreign } \\
\text { Investment }\end{array}$ & $\begin{array}{c}\text { Total Amount of Foreign } \\
\text { Investment Actually } \\
\text { Utilized, US \$100 million }\end{array}$ \\
\hline 2001 & 26,140 & 496.72 \\
2002 & 34,171 & 550.11 \\
2003 & 41,081 & 561.40 \\
2004 & 43,664 & 640.72 \\
2005 & 44,001 & 638.05 \\
2006 & 41,473 & 670.76 \\
2007 & 37,871 & 783.39 \\
2008 & 27,514 & 952.53 \\
2009 & 23,435 & 918.04 \\
$1979-2009$ & 684,918 & $11,416.22$ \\
\hline
\end{tabular}

Source: China statistical yearbook, 2010.

Table 2.

Total value of foreign direct investment in non-financial sectors and the growth rates in 2011.

\begin{tabular}{|c|c|c|c|c|}
\hline Sector & Enterprises & $\begin{array}{c}\text { Increase over } \\
2010(\%)\end{array}$ & $\begin{array}{l}\text { Actually utilized value } \\
\text { (100 million USD) }\end{array}$ & $\begin{array}{c}\text { Increase over } \\
2010(\%)\end{array}$ \\
\hline Total & 27,712 & 1.1 & 1160.1 & 9.7 \\
\hline \multicolumn{5}{|l|}{ Of which: } \\
\hline Agriculture, Forestry, Animal Husbandry and Fishing & 865 & -6.9 & 20.1 & 5.1 \\
\hline Manufacturing & 11,114 & 0.6 & 521.0 & 5.1 \\
\hline Production and Supply of Electricity, Gas and Water & 214 & 1.9 & 21.2 & -0.3 \\
\hline Transport, Storage, Post and Telecommunication Services & 413 & 4.3 & 31.9 & 42.2 \\
\hline Information Transmission, Computer Services and Software & 993 & -5.1 & 27.0 & 8.5 \\
\hline Wholesales \& Retail Trade & 7259 & 7.0 & 84.2 & 27.7 \\
\hline Real Estate & 466 & -32.4 & 268.8 & 12.1 \\
\hline Leasing and Business Services & 3518 & 2.9 & 83.8 & 17.6 \\
\hline Services to Households and Other Services & 212 & -2.3 & 18.8 & -8.2 \\
\hline
\end{tabular}

National bureau of statistics of China, February 22, 2012, statistical communiqué of the people's republic of China on the 2011 national economic and social development. 


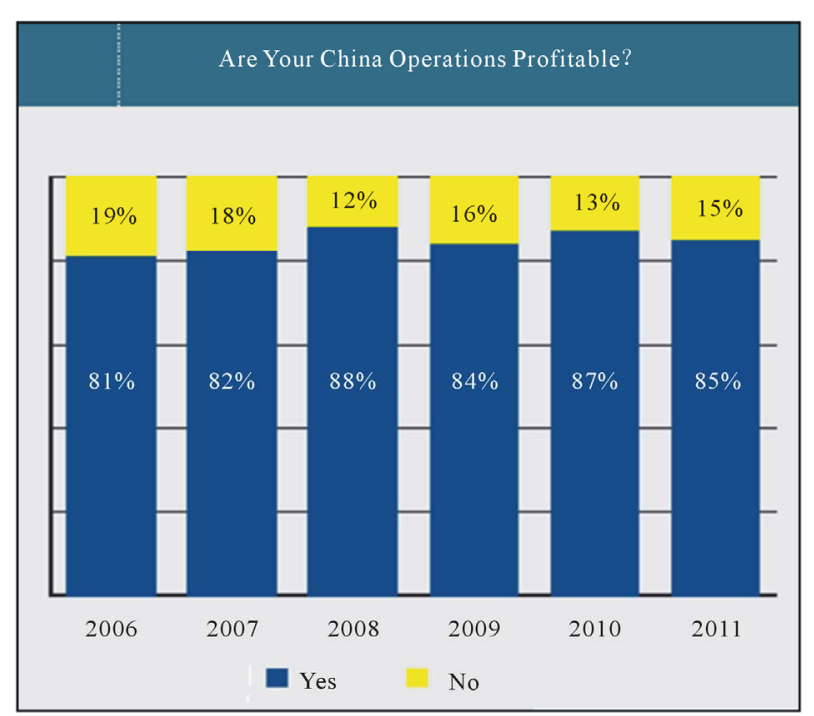

Figure 1.

US profitable firms in China. Source: US-China business council survey, 2011. https://www.uschina.org/info/members-survey

\section{The Changing Environment in Macro-Trend and in Specific Areas}

Thirty two years fast expansion has provided with tremendous investment opportunities to investors in China. Now the concern is whether the Chinese economy can achieve a soft landing under the challenges from the external and from the internal. A wide believe among the scholars from domestic and overseas is that the possibility of soft landing is larger. The supportive evidences include the strong supplies of basic growth factors such as labor, capital, technology, and creative research ability. China has the world highest national savings rate of almost $50 \%$ in the last decade. China still has about $40 \%$ labor employed in agricultural sector among them at least half could be released to industrial production. The needed technologies could either be purchased from developed countries or developed by China. Figure 2 shows the growth rates and absolute amount of GDPs of China for the past six years. The steady high growth trend and the fast enlarging absolute scale (US $\$ 7368$ billion) are very impressive.

To meet the challenges that the economy faces now the Chinese government has announced the new strategies of transiting the development pattern by promotion of domestic demand to balance the over-relying on external demand and by upgrading the industries to control the deterioration of environment and to reduce the heavy consumption of energy and other natural resources. A series of domestic demand promotion policies have been put in use, including reforms in housing policy to help low income people, increasing education subsidy, expanding medical care and social security coverage to rural areas and to low income groups in urban areas. Industrial upgrading strategy is targeting the seven strategic new industries such as energy saving industry, new generation of IT industry, biotech industry, high end equipments, green energy, new materials, and new energy automobiles. If all these measures were accomplished effectively, a soft landing of the economy and a good new starting point for sustainable growth would be possible.

Some researchers, for example, the Economists Intelligence
Unit forecasted an expected moderate growth of about $6 \%-8 \%$ for the Chinese economy for the coming five years as shown in Figure 3, which is similar to the growth target of the Chinese government.

To investors, though some traditional cost saving factors have disappeared, such as the cheap labor and land, tax incentives and good locations, some other new cost saving factors are emerging. These new factors include substantially improved infrastructure, large scale in production, good linkage of industries, better labor quality and more available professionals, still abundant labor and land, and other natural resources. Further, the market scale in China has been enlarged much bigger than before due to the income increase. The last, but also a very important factor is the strong local government support to industrial development in China all the time.

Meanwhile, investors in China need also to face the newly appeared problems such as the tightened social tension due to widened income gap and less hard working new labor hands in addition to the long standing ineffective legal system.

\section{The Opportunities}

The strategy of development pattern transition in Chinese

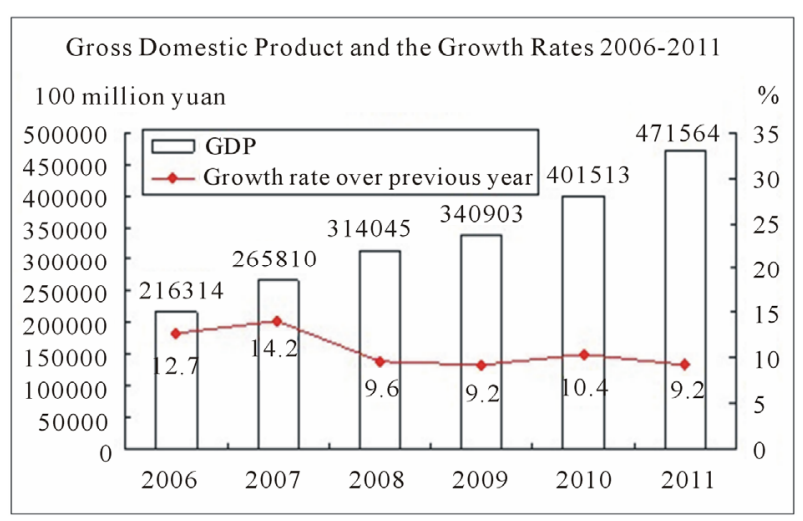

\section{Figure 2.}

China's real GDP and growth rates 2006-2011. National bureau of statistics of China, February 22, 2012, statistical communiqué of the people's republic of China on the 2011 national economic and social development.

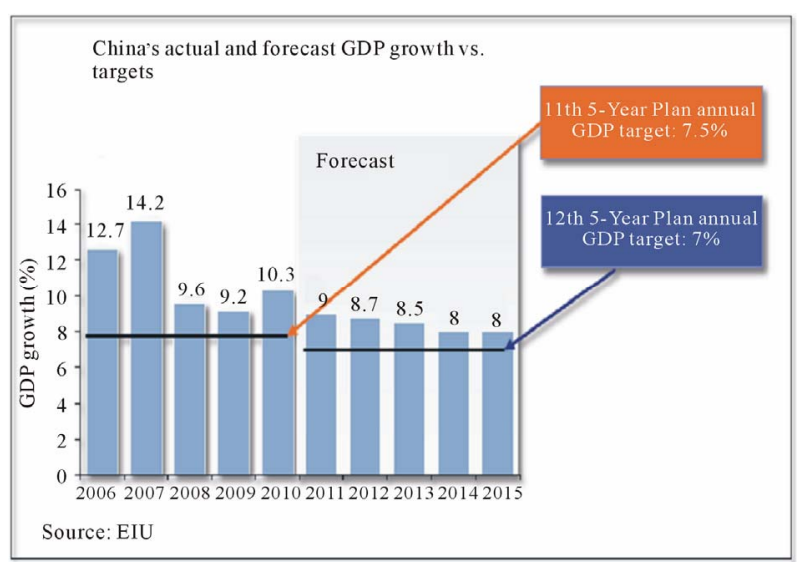

Figure 3.

The expected moderation of China's growth. Source: Economist intelligence unit. http://country.eiu.com/China 
economy will facilitate two big areas of development, promoting the seven new industries and balancing the widened income gap. Industrial structure upgrading involves government investments, subsidy and research support to the new industries production and to the use of the related products. This policy is more oriented to the developed coastal areas and big cities. The promotion of domestic demand involves enhancing the consumption power of low and middle income groups. At the same time, consumption goods and markets related to the majority of low and middle income groups will flourish.

Another long standing and large scale influential demand area is the fast urbanization in China. In 2011, the urbanization rate of China reached $50 \%$. In coming twenty years, there could be another $25 \%$ of the total population becoming urban residents from the rural areas. That means another three hundred and fifty million population movement. The Chinese government recently announced a new policy to loose the control of household registration system. At the county level, the old urban and rural two-status household system is abolished and at the large district level, farmers can conditionally move in urban areas without the barrier of registration. This new policy will certainly speed up the urbanization in medium and small cities. Construction industry and urbanization related products in these areas will be in a bigger demand.

The fourth major demand in China is the new movement to inland and western areas. Opening up the inland and western areas this time could be very much different from the case of early 1990 s when the government made a big plan of investment, but the consequence was not significant. The faster growth in inland areas recent years in the provinces such as Jiangxi, Hunan, Hubei, Henan, Chongqing and Sichun evidenced the capital flows driven by the market force. The government policy of promoting inland development is matching the market movement this time. This will form the new trend in locality for investment.

\section{The Risks and Uncertainties}

With the various changes in economic environment and the policy changes from governments, some risks and uncertainties for investment certainly exists. The changing areas which may generate risks and uncertainties include the slowdown of the external demand growth, pressure of Chinese currency (RMB) appreciation and inflation, labor cost increasing, domestic competition and mimicking products, constraints of resources supply, and the trade disputes. We will see how the changes in these areas possibly give rise to risks and uncertainties in investments in the following.

Slowdown of the external demand growth. Exports have been a major driving force second to investment in Chinese economy for the past twenty years (see Table 3). In 2011, China's exports reached US $\$ 1898.6$ billion. The majority of China's exports are manufacturing goods, accounted for $95 \%$ of the total. Among it, $60 \%$ of the exports are related to foreign direct investment companies. Slowdown of the external demand growth will limit these firms potential in the future. There are three factors which will limit the further expansion of China's exports. The first one is the slow recovery in developed economies. The very slow recovery of the US economy and the uncertainty of EU debts problem showed that these traditional large demanders for Chinese products will not be able to return to the normal track in the near future. The second factor is the large base of China's exports. In 2010, China's exports reached US $\$ 1477$ billion, surpassed EU to become the world largest exporter, accounting for $14.8 \%$ of the world total exports. The world market does not have further potential to absorb a faster increment of China's exports.

Pressure of RMB appreciation and inflation. Steady appreciation of RMB will definitely erode the advantage of some export firms. As mentioned above, these firms are more foreign direct investment ones. The pressure for RMB to appreciate

Table 3.

China's exports, imports, change, and trade balance, 2000-2011.

\begin{tabular}{|c|c|c|c|c|c|c|}
\hline & \multicolumn{2}{|c|}{ Exports } & \multicolumn{2}{|c|}{ Imports } & \multicolumn{2}{|c|}{ Surplus } \\
\hline & US $\$ 100$ million & $\%$ & US $\$ 100$ million & $\%$ & US $\$ 100$ million & $\%$ \\
\hline 2000 & 2492 & 27.9 & 2250 & 35.8 & 242 & -17.1 \\
\hline 2001 & 2662 & 6.8 & 2436 & 8.3 & 226 & -6.6 \\
\hline 2002 & 3256 & 22.3 & 2952 & 21.2 & 331 & 46.5 \\
\hline 2003 & 4384 & 34.6 & 4128 & 39.8 & 256 & -22.7 \\
\hline 2004 & 5934 & 35.4 & 5614 & 36.0 & 320 & 25.0 \\
\hline 2005 & 7623 & 28.5 & 6602 & 17.6 & 1021 & 219.1 \\
\hline 2006 & 9689 & 27.1 & 7915 & 19.9 & 1774 & 73.8 \\
\hline 2007 & 12,205 & 26.0 & 9561 & 20.8 & 2644 & 49.0 \\
\hline 2008 & 14,307 & 17.2 & 11,326 & 18.5 & 2981 & 12.7 \\
\hline 2009 & 12,016 & -16.0 & 10,055 & -11.2 & 1961 & -34.2 \\
\hline 2010 & 15,778 & 31.3 & 13,962 & 38.9 & 1816 & -7.4 \\
\hline 2011 & 18,986 & 20.3 & 17,435 & 24.9 & 1551 & -14.6 \\
\hline
\end{tabular}

Source: China statistical yearbook 2011, and China's statistical communiqué 2012. 
from the major trade partners of China, the developed economies, has been a long standing issue. They strongly believe that the rate of RMB is under valued which created the export advantage for Chinese firms. The evidence is the huge foreign exchange reserve that China accumulated over the past time and the persistent large amount trade surplus. The reserve in the end of 2011 was about US $\$ 3200$ billion. The trade surplus has been maintained around US \$200 billion annually since 2007 . In last three years, the surplus showed some declines.

Appreciation of RMB is on a clear trend. From 2005 to 2011, RMB has appreciated $31.7 \%$. A prediction by Tan 2003 for RMB rate is shown in Table 4. Up to now in 2012, the rate is US $\$ 1=$ RMB 6.3. The predicted value of Tan is very close to the current trend. With such a steady trend of appreciation of $\mathrm{RMB}$, affected firms could be the exporting firms and the low profit margin firms.

The concern of inflation appeared since 2010 after the huge stimulation plan during the 2008 crisis. Surplus of money supply due to the expansion fiscal policy and the huge foreign exchange reserve created the possibly long standing inflation pressure, which could similarly erode the advantages of export firms in China.

Labor cost increasing. Labor cost increasing and labor shortage in coastal areas and in big cities become a common phenomenon in recent years. In fact the labor wage increase is partly due to the inflation. We may view the so-called labor shortage as a market adjustment process in the new economic environment rather than an arrival of real labor shortage because from the potential labor supply to the actual labor wage in China, it is far from a real labor scarce country. The firms which have been relying on cheap labor need to adjust, while the other firms are not necessarily in such a situation. After all, labor abundant is still a major characteristic of China's resources endowments. Table 5 provides a comparison of the labor cost

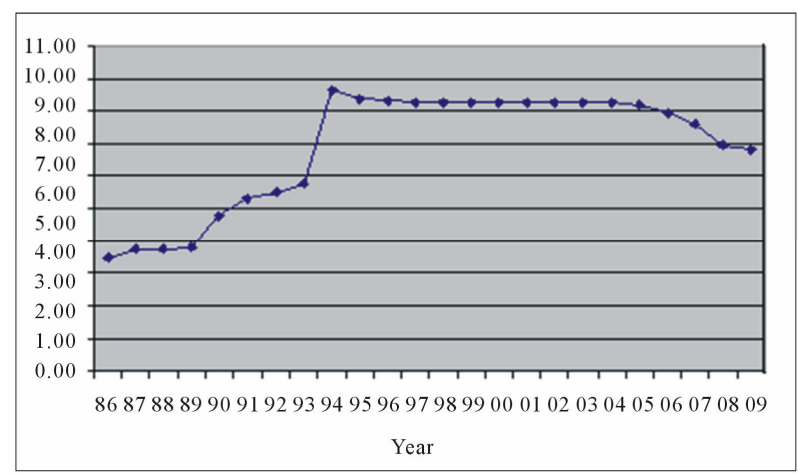

Figure 4.

Historical exchange rate of RMB, RMB/US \$. Source: China statistical yearbook. http://www.stats.gov.cn/tjgb

Table 4.

Prediction of the appreciation of Rinminbi.

\begin{tabular}{ll}
\hline 2003 & 8.3 \\
2005 & 8.1 \\
2015 & 5.8 \\
2025 & 2.8 \\
\hline
\end{tabular}

Source: Tan, China development report, 2003. in manufacturing in different countries. Obviously, the labor cost in China is still at the very low end.

Competition from domestic and mimicking products. A very widely complained business wrong doing by foreign investors in China is the ineffective protection of intelligent property rights. Even though the situation is improving, another fact is that Chinese people showed a very fast learning ability for the technology and the design of the foreign products. That means products with the feature of easy target for mimicking will face a quick appeared competition.

Environmental policy change. The energy and resources saving regulations from the government new policy will have a sizable impact to the firms who are not able to adjust and meet the requirements. The situation in China is that in many localities the enforcement of the old environmental regulations might not fully carried out. Due to the visible environmental deteriorations and increasing pressure from the public, the enforcement and more strict regulations will be in use. The firms in such a situation will be corrected, as we may have read from news of the pollution paper industries in the upper Yangzi river areas.

Constraints of resources supply. The supply of energy, water and minerals in China becomes increasingly pressured. According to the data of International Energy Agency, China surpassed US becoming the world largest energy consumption economy in 2009, total energy consumption of oil in 2009 was estimated to 2265 tons (Table 6). Though $70 \%$ of the energy supply in China is from coal, the daily average need of oil import is more than 500 barrels. Oil price increase due to the political tension of Middle East with the western countries puts a big uncertainty to the large energy consuming industries and firms in it.

Water supply in China is potentially an even serious problem. The recent official report (Shanghailist, 2012) indicates that two thirds of the Chinese cities have the problem of water shortage. North and western areas in China are the traditionally water scarce areas. Big and medium size cities water shortage becomes an uncertain constraint for the future development of the

Table 5.

International comparisons of hourly compensation costs in US dollars in manufacturing, 2010.

\begin{tabular}{cccc}
\hline Norway & 57.53 & United Kingdom & 29.44 \\
Switzerland & 53.20 & Spain & 26.60 \\
Belgium & 50.70 & Singapore & 19.10 \\
Denmark & 45.48 & Korea, Republic of & 16.62 \\
Sweden & 43.81 & Argentina & 12.66 \\
Germany & 43.76 & Hungary & 8.40 \\
Australia & 40.60 & Taiwan & 8.36 \\
France & 40.55 & Poland & 8.01 \\
United States & 34.74 & Mexico & 6.23 \\
Italy & 33.41 & China* & 2.00 \\
Japan & 31.99 & Philippines & 1.90 \\
\hline
\end{tabular}

Source: United Nations department of Labor, http://www.bls.gov/fls/. "China's data is from China statistical yearbook, 2010. 
Table 6.

Total energy consumption: US and China (Million tons of oil equivalents).

\begin{tabular}{lll}
\hline & US & China \\
\hline 2000 & 2270 & 1107 \\
2001 & 2228 & 1104 \\
2002 & 2254 & 1193 \\
2003 & 2260 & 1356 \\
2004 & 2306 & 1576 \\
2005 & 2317 & 1707 \\
2006 & 2295 & 1865 \\
2007 & 2333 & 1977 \\
2008 & 2281 & 2131 \\
$2009(\mathrm{e})$ & 2169 & 2265 \\
\hline
\end{tabular}

Source: IEA.

city and the industries there. Heavy water use investors should be aware of the potential water shortage problem for a specific investment location.

Trade disputes. Trade disputes between China and the developed economies occur more frequently in recent years. Although trade disputes of China with other nations are not a daily matter for every industry, the uncertainty for certain firms however increased.

\section{Conclusion}

Investment environment in China is going to change significantly due to the world economic environment change and the intrinsic evolution inside the Chinese economy. Many new challenges and different opportunities to investors are emerging. The main direction of the changes comparing to thirty years ago however is much clearer. An improved investment environment full with opportunities in China is appearing. The uncertainties and the challenges however need the investors to manage and to overcome with creativity.

\section{REFERENCES}

China Statistical Yearbook, various years. http://www.stats.gov.cn/tjgb

China's Statistical Communiqué (2012). http://www.stats.gov.cn/tjgb Economist Intelligence Unit (2010). http://country.eiu.com/China Fung, K. C. (2002). Foreign direct investment in China: Policy, trend and impact. Working Paper. Santa Cruz, CA: University of California.

Lu, H. (2012). Two thirds of Chinese cities face water shortages. Shanghaiist News.

Tan, K. Y. (2003). China development report, seminar report. Singapore City: Nanyang Technological University.

United Nations Department of Labor (2010). http://www.bls.gov/fls

US-China Business Council (2011). China business environment survey results. https://www.uschina.org/info/members-survey

Vanhonacker, W. R. (2004). The China casebook. Singapore City: McGraw Hill Education. 